November 15 in the Magga Dan, which is being shared with the Trans-Antarctic Fxpedition, and will arrive at Royal Society Base, Halley Bay, at the end of December 1936. They will relieve the advance party of ten men who sailed in the M.V. Tottan from Southampton on November 22, 1955, under the leadership of Surgeon Lieutenant-Commander David Dalgliesh. The main party will install the scientific equipment and erect huts so that the station is fully operating at the commencement of the International Geophysical Year on July 1, 1957. Colonel Smart will return to the United Kingdom at the beginning of January 1958; but the main party will remain at Halley Bay until the end of the International Geophysical Year on December 31, 1958. Colonel Smart, who is at present deputy director of Army health, Western Command, Chester, is forty-two years old. He graduated in medicine in the University of Aberdeen in 1936 and was commissioned into the Royal Army Medical Corps in the same year During 1948-49 Colonel Smart was a member of a War Office team working in the Arctic region of Canada and he returned to Northern Canada and Alaska in 1950

\section{An Optical Astronomy Observatory for the University of Michigan}

A GRANT of 545,000 dollars has been made to the University of Michigan by the National Science Foundation, Washington, D.C., for the support of studies leading to the establishment of an optical astronomy observatory. The studies are under the direction of Dr. Robert R. McMath, director of the McMath-Hulbert Observatory, and are a continuation of work undertaken last year by the University with the aid of previous grants totalling 300,000 dollars from the Foundation. The most recent grant to the University includes 30,000 dollars for a study leading to the erection of a solar telescope. The establishment of an optical astronomy observatory will include initially a 36 -in. and an 80 -in. telescope, and work so far has consisted of a search for a suitable site, the design and erection of equipment to test the sites, and work on the 36-in. telescope. The optics for this telescope are nearing completion at Yerkes Observatory. The test equipment consists of a 'seeing' tower which is erected on potential sites for the purpose of gathering data that will help guide the astronomers in selecting a spot where an observatory can operate with maximum efficiency. The tower is a triple-shelled steel structure, $60 \mathrm{ft}$. in height, equipped with a telescope that continually measures the turbulence in the atmosphere by gauging the size of the image of the star Polaris. This information, along with wind and temperature data, is transmitted to recording instruments situated at the base of the tower. The tower will make these automatic recordings over a period of more than eighteen months. The search for a site has now been reduced to approximately five sites, all of which are situated in the south-western United States because climatic and atmospheric conditions there are favourable and because it is one of the few remaining areas in the United States where an observatory can be erected a sufficient distance from the light and dust generated by cities. Four sites at present under study are Kitt Peak (6,800 ft.) in southern Arizona, the Sierra Ancha region (7,500 ft.) in central Arizona, Chevelon Butte $(6,900 \mathrm{ft}$.) in northern Arizona, and the Hualpai region $(7,400 \mathrm{ft}$.) in north-western Arizona. The Kitt Peak site is of special interest because it is on the Papago Indian Reservation. The mountain is sacred to the Papagos and the Papago Tribal Council granted special permission for the erection of a 'seeing' tower. Similar towers will be erected on other sites, including the Junipero Serra, California.

\section{European Bison from Poland}

Throvgr the Forestry Commission, Poland has generously presented to the United Kingdom a breeding pair of European bison. They arrived on October 9 and are in the London Zoo for a period of quarantine; afterwards they will be on show to the public and may later be transferred to Whipsnade. European bison are rare forest animals and, until the arrival of the pair from Poland, the Zoological Society had none in its care. Poland has between eighty and ninety European bison, representing, it is understood, a substantial proportion of world stocks ; the pair now in Britain are from a reserve near Cracow.

\section{Bristol Museum}

THAT the Bristol Museum plays an energizing part in the cultural life of the city and surrounding county is shown in the report of the city's Museum Committee for 1955. Although the main activities of the Museum are linked to the permanent exhibits, fifteen major temporary exhibitions were also arranged; these ranged from geology as illustrated by railway posters to a collection of postage stamps issued in the nineteenth century. A special feature is arranged each month to show either objects on loan or recently given. The city archivist has provided material each quarter for a special case while the city librarian exhibits local documents of topical interest. The Bristol Society of Architects has devised illustrations which enable visitors to understand and appreciate the principles of architecture, examples being drawn from the locality. As in previous years, six lectures have been provided during the winter months to audiences of more than three hundred at each session. Conducted summer walks have again been arranged, some of the walks attracting so many visitors that they have been embarrassing to conduct. The staff of the Museum was again invited to give many lectures to various organizations, while an interesting development was the loan of small assemblages of zoological and botanical material to H.M. Prison at Falfield. Classes from all types of schools have visited the Children's Room. The demands in history and natural history are now approximately equal; but although the room is in constant use during term-time, requests exceed the number which it is possible to accommodate. The Saturday Nature Club, now more than a year old, has been enthusiastically attended by $50-60$ members each week, chiefly older primary school children. This is a record of which Bristol Museum might well be proud and should serve as a model for other areas.

\section{Trinidad and Tobago Forest Department : Report for 1954}

THE annual report for 1954 of the Trinidad and Tobago Forest Department (pp. $44+1$ map. Trinidad : Government Printing Office, $1955 ; 36$ cents) gives a statement of the present areas of forestry in the Islands. Their total area amounts to 1,863 and 116 square miles, respectively, practically all of which is below a thousand feet. In Trinidad and 